\title{
PLOT DAN SUDUT PANDANG DALAM BINGKAI WACANA IDEOLOGIS: ANALISIS CHRONOTOPIC TERHADAP NOVEL KORUPSI KARYA TAHAR BEN JELLOUN MELALUI KERANGKA TEORI DIALOGIS M.M. BAKHTIN
}

\author{
Dian Nurrachman \\ Dosen Sastra Inggris Fakultas Adab dan Humaniora \\ UIN Sunan Gunung Djati Bandung
}

\begin{abstract}
ABSTRAK
Sastra merupakan sebuah rekreasi atau penciptaan kembali keseluruhan pengalaman hidup melalui sudut pandang sang pengarang. Frasa 'keseluruhan hidup' dapat dimaknai sebagai apapun; kehidupan sosial, politik, budaya, ekonomi, dan bahkan objek-objek dari dunia terdalam manusia, seperti kehidupan emosi, pikiran dan perasaaan. Sebagai salah genre sastra dan merupakan bagian dari prosa fiksi naratif, novel juga berusaha untuk merekreasi keseluruhan pengalaman hidup itu; ia berusaha untuk menjadi semacam rekaman dari segala apapun yang hadir dan teralami oleh pengarang. Akan tetapi, senyatanya sebuah novel tidak pula hanya merupakan sebuah rekaman belaka, ia hadir di tengah-tengah kehidupan manusia sebagai potret yang jujur dalam hubungannya dengan prinsip-prinsip kemanusiaan: kebebasan dan keadilan (amr ma'ruf) dan kritik sosial, budaya, politik dan ideologi (nahy munkar). Tulisan ini mencoba masuk pada tataran ideologis dari potret kemanusiaan tersebut yang terepresentasikan dengan baik dalam novel Korupsi karya Tahar Ben Jelloun. Melalui fakta tekstual plot dan sudut pandang dalam bingkai chronotopic (satuan ruang dan waktu), tulisan ini diharapkan bisa membuktikan bahwa struktur teks akan selalu berhubungan dengan konteks, di mana sumber pengalaman ditransformasikan ke dalam fakta-fakta cerita secara ideologis.
\end{abstract}

Key Word: Plot, Sudut Pandang, Ideologi, Chronotopic, Teori Dialogis.

\section{PENDAHULUAN}

Novel yang berjudul Korupsi (yang ditulis dalam Bahasa Prancis dan berjudul asli L'Homme Rompu) karya Tahar Ben Jelloun adalah sebuah novel yang menarik. Novel ini menghadirkan sebuah potret yang jujur dalam melihat realitas sosial, budaya, politik, dan ideologi masyarakat secara umum dalam kaitannya dengan 'korupsi'. Dengan mengambil latar beberapa kota dan sisi kota yang ada di Maroko, novel ini tampak dengan cukup gemilang memainkan emosi dan kesadaran tokoh dan dengan jujur membuat sang tokoh utama, 'aku', yang sekaligus menjadi narator akhirnya 'menyerah' terhadap ideologi korupsi masyarakat yang oleh para tokoh lainnya disebut sebagai 'keluwesan sistem'. Permasalahan yang lebih menarik kemudian justeru terletak pada fenomena empiris dari struktur tekstual/ komposisi cerita (termasuk penggunaan bahasa) dan wacana atau struktur makna cerita itu. Sebagai contoh, pada konteks yang pertama saya menemukan adanya peralihan sudut pandang 
(point of view) yang cukup tajam dari 'sudut pandang orang ketiga maha tahu' (third person omniscient point of view) ke 'sudut pandang orang pertama' (first person point of view) tanpa ada keterangan apapun baik dari dalam cerita maupun keterangan tambahan dari pengarang. Sedangkan contoh dari permasalahan wacana adalah konteks korupsi yang dihadapi justeru pada awalnya oleh tokoh yang punya keteguhan kepribadian dalam menentang korupsi itu sendiri namun tidak tahan akan godaan untuk ikut larut dalam 'keluwesan sistem' itu.

Dua permasalahan menarik di atas adalah representasi dari sistem kesastraan yang akan selalu berada di dua sisi, yaitu sisi bentuk dan sisi isi. Sehingga, sebuah novel sudah selayaknya dipandang sebagai karya sasta yang tidak hanya menghadirkan sebuah cerita dengan pelbagai macam teknik komposisinya (how indicators), tetapi juga harus dipandang dalam hubungannya dengan konteks mengapa cerita itu layak dihadirkan kepada sidang pembaca (why indicators). Dalam konteks ini, M.M. Bakhtin telah sejak lama mencoba memahamkan kita bahwa sebuah 'Novel' pada saat yang sama merupakan suatu fenomena empiris (sebuah teks tertulis) dan juga kategori transendental. Ia tidak hanya merupakan sebuah fakta dari sejarah sastra tetapi juga merupakan bentukbentuk sosialitas (sociality) dan subjektivitas (subjectivity) yang menjadi bagian dari kehidupan keseharian manusia (lihat Pechey, 2007: 105). Bagi Bakhtin, berbeda dengan puisi, novel cenderung lebih mengusung konsep yang betul-betul 'dialogis'. Bahkan untuk drama sekalipun, novel (sebuah novel yang baik) tetap lebih unggul dalam menampilkan konsep dialogis ini karena di dalam novel tidak ada proses (penunjukan) individuasi secara langsung seperti apa yang ditampikan di dalam drama. Sebuah novel dikatakan bersifat dialogis jika wacana yang dihadirkan tidak berorientasi pengarang sebagai pusat (non-author/itarian) melainkan membiarkan wacana itu dibicarakan oleh para tokohnya (termasuk narator); kesadaran para tokoh dibiarkan mengalir seadanya tanpa campur tangan pengarang dalam menilai suatu permasalahan/peristiwa/wacana tertentu (lihat Selden, Widdowson, dan Brooker, 2005: 40).

Konsep dialogis (dialogism) itu sendiri adalah sebuah realitas wacana yang tidak tetap dan bergantung pada dua ketidakmungkinan: suatu pengalaman seseorang sebagai dua orang sekaligus yang, jika disadari, akan membawa kita kembali pada yang satunya lagi dengan mereduksi dua sampai beberapa unit mekanis (lihat Pechey, 2007: 111-112). Melalui perspektif dialogis ini, kita bisa melihat secara jelas apakah cerita dan wacana sebuah novel tampak alamiah atau justru merupakan corong ideologis dari seorang pengarang secara langsung. Proses analisis ke arah ini menjadi penting karena bagi Bakhtin, tindak tutur bahasa adalah sistem tanda alamiah yang maknanya dimodifikasi dan ditransformasi melalui kecenderungan sosial, penilaian, dan konotasikonotasi yang memadatkan dirinya sendiri dalam kondisi sosial yang spesifik (lihat Eagleton, 1996: 101). Dengan kata lain, bagaimana makna bahasa (wacana) yang ditampilkan sebuah novel itu termodifikasi dan 
tertransformasi secara alamiah melalui hal-hal yang diungkapkan Bakhtin tersebut atau tidak, menjadi bagian penting ketika kita mau menganalisis novel dari perspektif ini.

Sebuah novel hanya akan tetap menjadi fakta sejarah sastra saja jika para pembaca tidak pernah menganggapnya sebagai kategori transendental yang dapat memahamkan mereka tentang pengalaman hidup seseorang dalam kerangka kebudayaannya. Prinsip dialogis Bakhtin yang meliputi fenomena empiris dan kategori transendental ini harus diposisikan sebagai kerangka konseptual pertama ketika kita ingin membedah novel dari perspektif dialogis. Oleh karena itu, penulis mencoba menempatkan objek pembahasan, yaitu novel Korupsi kaya Tahar Ben Jelloun, pertamanya ke dalam satu koherensi struktur tekstual sebagai bagian dari fenomena empiris dan/atau fakta kesastraan. Dalam konteks ini, beberapa sarana kesastraan (literary devices) dari novel Korupsi ini akan dicoba untuk dieksplorasi, khususnya yang menyangkut konsep Chronotopicity dalam teori dialogisnya Bakhtin.

\section{PEMBAHASAN}

Bakhtin mendefinisikan chronotope sebagai "the intrinsic connectedness of temporal and spatial relationships that are artistically expressed in literature" (dalam Pechey, 2007: 84). Ini berarti bahwa apapun yang menjadi sarana kesastraan-plot, tokoh, sudut pandang, dan latar-termasuk ke dalam chronotope, sehingga pembahasan mengenai chronotope tidak terfokus pada satu sarana kesastraan, tetapi lebih mengedepankan keterkaitan di antara semuanya. Dalam novel Korupsi, penulis menemukan keunikan chronotope dalam konteks plot dan sudut pandang yang sepintas lalu mungkin terkesan sebagai ketidakjelasan susunan plot yang biasa ditampilkan sebuah novel. Ketika pembaca disuguhi awal cerita dengan gaya in medias res (di tengah-tengah sesuatu hal), maka dengan segera kita dikenalkan dengan tokoh yang akan memandu kita mengenali dunianya sebagai bentuk permulaan keberadaan (the beginning of the existence).

Sebagaimana biasa, bus terlambat, dan ketika tiba, di dalamnya telah penuh sesak, seakan mau pecah. Murad memandang arlojinya. Dia harus memilih, apakah tetap bertekad naik bus dengan menyikut kiri-kanan, mendorongdorong dan menginjak kaki orang lain, atau batal menumpangi kendaraan itu dengan risiko terlambat di kantor. (Tahar Ben Jelloun, hal. 13).

Kutipan di atas menunjukan satu bentuk permulaan yang secara langsung menggambarkan satu sisi kehidupan tokoh (utama), yaitu Murad. Bagaimanapun, kesan yang muncul di benak pembaca pertama kalinya adalah bahwa Murad merupakan 'pegawai biasa' dengan pangkat rendahan. Terlebih lagi, dengan teknik sudut pandang orang ketiga maha tahu seperti di atas, maka pembaca digiring untuk memahami konteks pikiran tokoh secara langsung (kata 'harus' dalam klausa 'Dia harus memilih' membuktikan hal ini) dan membuatnya menjadi semacam juxtaposition atau gabungan antara 
gaya in medias res dan sudut pandang orang ketiga maha tahu.

Sayangnya, juxtaposition yang unik seperti kutipan di atas kemudian tidak didukung dengan prinsip chronotope dalam konteks intrinsic connectedness; hal ini karena Murad pada kenyataannya bukanlah 'pegawai biasa' dengan pangkat rendahan, namun justeru seorang 'Wakil Direktur Perencanaan dan Pembinaan' yang kemudian diketahui berada di 'Kementerian Pekerjaan Umum'.

Murad seorang insinyur. Perannya di jajaran birokrasi adalah mempelajari berkas pembangunan. Tanpa parafnya, tak akan ada izin membangun. Itu posisi yang penting dan banyak diincar orang. Nama jabatannya sendiri kedengaran hebat, "Wakil Direktur Perencanaan dan Pembinaan".

"Dengan gajinya yang sedikit, dia menghidupi keluarganya, membayar uang sekolah anakanak, sewa rumah, dan memenuhi keperluan sehari-hari ibunya. Itu tidak cukup. Dia hidup berutang berkat kebaikan pemilik warung tetangga. (Tahar Ben Jelloun, hal. 15).

Menurut saya, gaya paradoks seperti kutipan di atas (masih bagian permulaan) tampak sedikit berlebihan karena disebutkan bahwa gaji Murad itu sedikit, sehingga rumahnya pun rumah sewa. Bagi penulis, ini merupakan suatu unsur yang menyepelekan kelogisan plot; sebuah tindakan gegabah dan naif dari pengarang demi sebuah 'moralitas' yang ada dalam cerita dan membuat chronotope menjadi tidak berkaitan baik dalam ruang maupun waktunya. Walaupun begitu, peralihan sudut pandang justeru melahirkan keunikan tersendiri dalam novel ini. Di halaman 24, sudut pandang yang pada awalnya adalah orang ketiga maha tahu (third person omniscient) dan berada di luar cerita (non-focalized narrative) beralih menjadi orang pertama (first person) dengan 'Aku' atau Murad sebagai narator yang membuatnya terlibat secara langsung di dalam cerita (internally focalized narrative).

Memang benar, aku tak pernah bisa menyesuaikan diri, seperti yang mereka katakan. Apa artinya menyesuaikan diri? Itu artinya melakukan berbagai hal seperti yang dilakukan orang, menutup mata bila perlu, menyisihkan prinsip dan idealisme, tidak menghalangi 'sistem' yang berjalan, pendeknya belajar maling dan berbagi keuntungan dengan yang lain. Aku tidak bisa begitu. Bohong pun tak bisa. (Tahar Ben Jelloun, hal. 24).

Peralihan ini membuat plot sedikit lebih longgar tapi kemudian justeru mampu menguatkan karakterisasi Murad sebagai tokoh yang berperan kemudian sebagai narator sekaligus. Wayne C. Booth menyebut konteks seperti ini sebagai 'the self-conscious narrator' yang berfungsi sebagai penguatan narator dalam hubungannya dengan penyampaian cerita kepada pembaca (lihat dalam Williams, 2004: 61). Dalam posisi ini, peralihan sudut pandang juga menimbulkan efek 
keterlibatan emosional yang lebih intens, karena sebagai salah satu bagian dari chronotope, sudut pandang dan plot dapat memunculkan dialogisme secara bersamaan. Hal ini seperti yang diungkapkan oleh Pechey (2007: 85) bahwa "What they reveal, moreover, is that a certain reflexivity characterizes both articulations: both the novel's dialogism and its chronotopicity partake of a certain self-reference that clings to all signification and all reference whatever." Lebih lanjut, Pechey (2007: 85) menambahkan bahwa "If the novel as dialogue, in Bakhtin's strong sense, is the name for discourse as autocritique -that is, discourse in its critically selfsignifying mode - then the novel as narrative is discourse thematizing its own ineluctable situation in space and time." Jadi dapat dikatakan bahwa konteks peralihan narator dalam plot yang paradoks seperti yang ada di novel Korupsi ini merupakan sebuah bentuk dialogis tersendiri yang menyaran pada wacana sebagai bentuk otokritik, atau dengan kata lain, novel Korupsi nya sendiri sebagai teks yang independen merupakan sebuah novel otokritik.

Konteks selanjutnya yang menjadi bagian dari plot Korupsi ini-yang menarik-adalah ketika sang tokoh utama, Murad, mulai mempertanyakan 'kesalehan' dia sendiri dalam satu masyarakat yang nota bene hampir semuanya masyarakat korup. Bagian ini merupakan awal mula adanya perumitan masalah atau yang sering diistilahkan dengan complications.

Sampai berapa lama aku akan bangga begini? Apakah kebanggan itu akan memungkinkanku membiayai studi anak-anakku, membayar obat-obatan bagi si bungsu yang mengidap asma, memberikan biaya berlibur bagi keluarga kecilku? (Tahar Ben Jelloun, hal. 51).

Sebagai sebuah chronotope, bagian plot di atas tentunya akan selalu terkait dengan ruang dan waktu. Sehingga, konteks yang dipertanyakan Murad di bagian tersebut pada dasarnya adalah suatu hal yang wajar; sebuah keluarga akan tetap bertahan jika kebutuhan dasarnya (sandang, pangan, papan) dapat terpenuhi dengan baik, dan untuk memenuhi itu maka diperlukan sarana yang fundamental, yaitu uang yang cukup. Pandangan seperti ini menyatu dalam konteks ruang dan waktu manusia di manapun ia berada, terlebih lagi di dalam konteks masyarakat modern yang mengutamakan budaya konsumtif dan hedonis.

Tidak hanya itu, sebagai sebuah chronotope, kesan ideologis yang ditampilkan dari bagian complications itu justeru semakin kuat karena pertanyaan-pertanyaan yang diajukan Murad memang pertanyaan sederhana, yang lazim diajukan oleh semua orang. Sehingga, pembaca pun sudah diarahkan bahwa bagian itu merupakan titik awal perubahan dan sekaligus titik akhir 'kesalehan' Murad. Satu hal yang menjadi catatan mengapa penulis menyatakan itu, karena bagian-bagian selanjutnya-sampai sebelum Murad betul-betul berubah-hanya merupakan lintasan-lintasan peristiwa yang dialami Murad (yang sekaligus sebagai narator). Lintasanlintasan peristiwa itu 
menggambarkan hal yang sama, yaitu konflik batin Murad akibat dari tekanan-tekanan sosial yang mencoba mempengaruhi dia untuk masuk ke dalam 'keluwesan sistem', atau yang sering disebut Murad sendiri sebagai sistem korup.

Tumben, ada suara berbisik dalam diriku, "Tapi kau bisa mengubahnya. Kondisimu ada dalam kedua tanganmu. Kau tak akan naik bus sialan ini seumur hidupmu. Pada suatu hari ia akan melemparkanmu ke selokan umum! Bangunlah, pikirkan masa depan anakanakmu. Yang kamu sebut korupsi, sebenarnya hanyalah cara lain dari mendapatkan kembali apa yang sesungguhnya menjadi hakmu. Semua orang bisa mengatur. Jadilah luwes, temanku. Keluwesan adalah kehidupan. (Tahar Ben Jelloun, hal. 56).

Kamu bisa saja mengubah keadaanmu. Kamu bisa saja memberikan kepada istri dan anak-anakmu kehidupan yang lebih pantas, lebih benar, lebih luwes. Ya temanku tercinta, keluwesan, keluwesan...dan akan kamu lihat berbagai hal akan datang susul menyusul dengan sendirinya. (Tahar Ben Jelloun, hal. 57).

Tidak dapat disangkal bahwa bagian yang dikutip di atas merupakan tahap selanjutnya dari plot novel Korupsi ini, yaitu tahap krisis (crisis) yang di dalamnya terdapat konflik. Walaupun konflik yang dialami Murad pada bagian ini adalah konflik batin (inner conflict), tapi karena selalu terkait dengan prinsip chronotopicity maka konflik batin inilah yang menjadi konflik yang sebenarnya. Hal ini sesuai dengan konsep dialogisme nya Bakhtin bahwa "To tell a story is to dramatize the spatial difference and temporal deferral thanks to which telling is at once made both necessary and possible" (dalam Pechey, 2007: 85). Jadi, sebagai bagian dari chronotope konflik batin yang dimunculkan itu berfungsi sebagai sarana untuk mendramatisasikan kehidupan Murad dalam ruang dan waktu yang dibuat berdasarkan kepentingan dan kemungkinan akan adanya realitas kehidupan seperti yang dijalani Murad sendiri.

Ini berkaitan juga dengan prinsip Bakhtin dalam konteks bahasa, bahwa bahasa merupakan lapangan pertarungan ideologis di mana sistem pertandaan yang ada di dalamnya merupakan ideologi itu sendiri karena tidak akan pernah ada nilai atau gagasan tanpanya (lihat Eagleton, 1996: 102). Ini berarti bahwa tindak tutur bahasa yang secara abstrak ada dalam pikiran Murad seperti yang tampak pada konflik batin di atas secara ideologis menjelma tidak hanya sebagai chronotope tetapi juga sebagai ideologi itu sendiri. Sebuah ideologi tentunya adalah bagian dari hubungan sosial yang pasti, atau dengan kata lain, sebuah ideologi harus dilihat dari perannya dalam realitas sosial, di mana pelbagai macam asumsi, persepsi, opini, argumentasi, dan sudut pandang saling berbenturan satu sama lain, saling berebut tempat untuk diakui sebagai yang benar, atau yang paling benar, walaupun pada kenyataannya sering yang benar adalah salah dan yang salah adalah benar. Jelaslah bahwa bagi Bakhtin, bahasa kemudian tidak dipandang baik 
sebagai 'ekspresi', 'refleksi' ataupun sistem abstrak, akan tetapi lebih sebagai tujuan produksi material, di mana makna tanda-tanda ditransformasi melalui proses konflik sosial dan dialog menuju kebermaknaan (lihat Eagleton, 1996: 102).

Apa yang muncul selanjutnya dalam konteks plot sebagai chronotope adalah bagaimana jebakan episode crisis berhasil menjebak dan mengubah Murad hampir dalam segala hal; pandangan hidup, sikap, perilaku, dan bahkan moralitas. Ini mungkin tidak banyak diharapkan oleh pembaca umum yang boleh jadi merasa dipermainkan oleh Murad, karena-meminjam istilah dari teori Reader Responsenya Hans Robert Jauss-'horison harapan' (the horizon of expectation) pembaca banyak yang satu arah (linear) dengan moralitas (kesalehan) Murad di awal cerita.

Ada ketukan di pintu. Si pesuruh masuk membawa segelas teh dan menanyakan kabar anakanakku. Tampaknya seseorang telah memberi tahu dia. Kuucapkan terima kasih. Aku minum seteguk teh, kemudian kukeluarkan bungkusan uang dari kantongku dan membaginya menjadi dua bagian dalam dua amplop kekuning-kuningan yang kukunci di laci sebelah kanan. Kutandatangani seluruh berkas, bahkan tanpa membacanya terlebih dahulu, lalu menekan bel.

$\mathrm{Si}$ pesuruh tiba dengan cepat. Kuulurkan berkas itu dan memintanya untuk menyampaikannya ke bagian kurir. Aku menarik napas panjang tanda kelegaan. Ternyata itu sederhana saja, cepat dan tidak bersifat tragis. Aku gila telah membebani diriku dengan begitu banyak pertimbangan. Aku telah melewati ambang pintu. Aku bukan lagi orang yang sama, bahkan aku akan menjadi lebih baik. Kubuka salah satu amplop itu dan kutarik dua lembar biru bernilai dua ratusan dirham. Lembaran uang it merupakan uang baru, bersih sekali dan masih bau percetakan. Kukunci lagi laci dan kutinggalkan kantor. (Korupsi, hal. 77).

Kutipan di atas membuktikan bahwa sebuah plot tidak harus selalu linear, karena pada dasarnya (plot) kehidupan manusia juga tidak selalu linear. Yang menjadi penting kemudian justeru bukanlah prinsip linearitas, melainkan bagaimana ruang dan waktu (chronotope) menjadi satu hal yang dominan dalam proses kehidupan; kebaikan, kesalehan, kejelekan, kemunafikan, semuanya berproses dalam ruang dan waktu yang tentunya tidak (selalu) linear. Maka, dalam konteks ini, peralihan sudut pandang menjadi salah satu kunci dari ketidaklurusan plot. Dengan menggunakan sudut pandang 'aku' dan menjadikannya sebagai tokoh utama sekaligus, maka si 'aku' dengan leluasa bercerita tentang tubrukan-tubrukan aspek kehidupan yang saling mempengaruhi dalam satu nuansa keserempakan. Di sanalah konteks spasio-temporal (ruang dan waktu) menjadi penting yang kemudian penjadi prinsip chronotope. Hal ini sesuai dengan pernyataan Pechey (2007: 85) bahwa "Chronotopic analysis insists that the story's particulars only signify in so far as they have always already established 
in the most general way the spatiotemporal worldliness of the world."

Selain dari itu, emosi pembaca juga pada akhirnya bisa teraduk-aduk, ketika Murad, sang narator, berusaha meyakinkan pembaca bahwa keterjebakan dia bukanlah satu hal yang perlu disesali. Keterjebakan dia untuk menjadi seorang yang 'luwes' adalah konsekuensi dari keterdesakan sosial-politik-ekonomi yang hadir dalam keserempakan ruang dan waktu yang sama. Bahkan, keterdesakan itu diungkapkan dengan sangat naif, misalnya karena dia perlu mewujudkan angan-angan anak keduanya, Karima, yang selalu memimpikan liburan ke Tangier.

Uang haram memberi sayap. Tetapi arti kebebasan itu? Aku bebas dari kungkungn Hilma dan ibunya. Itu sesuatu yang penting sekali. Namun, bila kuteruskan sampai ujung, misalnya memulai kehidupan baru dengan Nadia, aku akan mendapat lebih banyak lagi. Tetapi, untuk saat ini, yang paling penting adalah aku berhasil mewujudkan liburan kecilku dengan anak perempuanku. Akan kuberikan kejutan baginya. Dia tak perlu masuk sekolah pada hari Jumat, kami akan belajar di kereta api. (Tahar Ben Jelloun, hal. 93).

Kutipan di atas merupakan bukti bahwa manusia tidak pernah linear dalam menyikapi sesuatu; selalu ada yang baru yang menjadi sandaran penyikapan itu walaupun itu bagian dari sikap amoral. Ideologi inilah yang ingin dikedepankan dalam konteks kalimat, "Tetapi, untuk saat ini, yang paling penting adalah aku berhasil mewujudkan liburan kecilku dengan anak perempuanku". Kalimat seperti ini adalah kalimat yang betul-betul ideologis, lahir dari kesadaran akan pentingnya sesuatu (liburan) sebagai bagian dari proses interaksi sosial. Di sinilah Bakhtin berperan lagi; ketika novel ini sudah dapat dikategorikan sebagai karya 'dialogis' dengan mengedepankan prinsip-prinsip chronotope sebagai dasarnya, maka sisi ideologis sebuah bahasa akan dengan mudah terlihat sebagai bagian dari model dialogis. Model dialogis itu sendiri kemudian memposisikan sebuah model lain yang mana tindak tutur bahasa secara sosial tidak dapat direduksi dan subjektivitas tak berarti apapun jika terlepas dari intersubjektivitas (lihat Booker, 1996: 111).

Kemudian, bagian plot selanjutnya yang penting untuk dibahas dalam hubungannya dengan plot sebagai chronotope adalah bagian klimaks (climax). Bahkan, penulis berasumsi bahwa setelah beberapa bagian termasuk crisis, maka bagian selanjutnya sampai akhir novel merupakan klimaks, karena beberapa konteks ceritanya sendiri tidak mendapatkan apa yang biasa dalam plot linear disebut sebagai resolusi (denoument). Sekali lagi, ini membuktikan bahwa sebuah novel yang bersifat dialogis tidak akan menyelesaikan cerita secara menyeluruh. Selalu ada ruang-ruang terbuka untuk diisi oleh pembaca karena plot tidak (pernah) bersifat linear. Kekacauan rumah tangga Murad; hubungannya yang tidak jelas (tidak mendapat kejelasan) dengan Nadia, sepupu yang yang dicintainya dan juga mencintainya; ketidakjelasan hubungan juga dengan perempuan (mahasiswi, perawat) 
yang kebetulan bernama Nadia juga, yang terkesan hanya sebagai sebuah dekorasi tekstual terhadap konteks tekanan sosial Murad; dan ketidakjelasan posisi Murad secara moral terhadap korupsi itu sendiri kemudian beserta segala hal yang ia lakukan (termasuk perselingkuhan dan adegan seksual dengan Nadia yang mahasiswi/perawat); semuanya merupakan unsur-unsur klimaks plot yang tak pernah mendapat akhir/resolusi sampai akhir novel.

Wacana ideologis yang begitu jalin-menjalin berkelindan dan bahkan begitu rumit karena tidak pernah berada di posisi yang fix berbenturan dengan horison harapan pembaca, pada akhirnya, atau bahkan dengan tujuan pengarang. Hal inilah yang secara eksplisit disebut oleh Bakhtin sebagai wacana polifonik (polyphonic discourse) sebuah novel, dimana terdapat "a plurality of independent and unmerdged voices and consciousness, a genuine polyphony of fully valid voices" (Abrams, 1999: 63). Konsep wacana polifonik ini besandar pada konsep Bakhtin sendiri mengenai novel, karena baginya, novel didefinisikan sebagai "a diversity of social speech types (sometimes diversity of languages) and a diversity of individual voices, artistically organized"(Bakhtin, 2001: 1192). Oleh karena itu, sebuah novel akan selalu dirupakan oleh multiplisitas perbedaan dan pertentangan suarasuara sosial yang mencapai makna penuhnya hanya dalam proses interaksi dialogis antara satu tokoh dengan yang lainnya atau dengan suara narator (lihat Abrams, 1999: 63).

\section{KESIMPULAN}

Secara umum, novel yang berjudul Korupsi karya Tahar Ben Jelloun ini sudah dapat dikategorikan sebagai sebuah novel yang baik versi Mikhail Bakhtin. Hal ini mengacu pada semua jenis chronotope yang secara spesifik ditujukan pada plot dan sudut pandang dalam novel ini. Seperti yang sudah dikutip sebelumnya, bahwa pada dasarnya analisis chronotopic menekankan bahwa aspek partikular cerita hanya bermakna jika dihubungkan dengan wilayah spasio-temporal keduniaan sebuah dunia. Secara jelas, kita melihat itu semua dalam konteks kehidupan Murad. Tekanan-tekanan sosial, ekonomi, dan politik yang terus-menerus mendera Murad menjadikannya berubah haluan ideologi. Terlepas apakah kita, sebagai pembaca, menyayangkan atau tidak perubahan haluan ideologi ini, yang jelas kita harus mengakui bahwa novel ini sendiri adalah sebuah novel ideologis; menempatkan satu subjek ideologi ke dalam jalinan cerita yang pada dasarnya sederhana. Kerumitan muncul karena begitu banyak suara yang menekan, menghimpit, menerjang, bahkan menerkam kehidupan Murad, dan disanalah aspek polifonik menjadi hadir ke tengah-tengah pembaca.

Selain dari itu, kecerdikan sang pengarang, Tahar Ben Jelloun, dalam mengubah aspek sudut pandang tetap menjadi kunci utama novel ini masuk ke dalam kategori novel dialogis/polifonik. Tanpa peralihan sudut pandang, maka cerita hanya akan bersandar pada narator yang derajat kepercayaaannya bisa jadi diragukan (unreliable narrator), terlebih lagi ketika narator itu bersifat maha tahu (omniscient). 
Sebagai penutup dari esei ini, penulis hendak mengatakan bahwa kesimpulan akan tetap menjadi milik semua pembaca. Secara tersurat, bahkan kita mendapatkan pesan ini (sebagai salah satu bentuk wacana ideologis) dari pernyataan narator secara langsung, yang kemudian juga menjadi aspek terakhir dari analisis chronotopic berdasarkan pada metode kritik (prinsip) dialogis-nya Bakhtin, seperti yang dikutip di bawah ini.

Kisahku belum berakhir. Aku tidak begitu tahu akhir kisah ini. Aku menulisnya sedikit demi sedikit, mengalir selaras dengan perkembangan yang terjadi. Karena itulah kisahku ditulis dalam kala kini. Mungkin dengan menuliskannya, faktafakta ini tampil secara tidak disangka-sangka, bahkan juga kata-kata yang muncul mewarnai perkembangannya. Bila pada akhir cerita ini aku bebas, itu berkat persekutuan kata-kata. (Tahar Ben Jelloun, hal. 217).

\section{DAFTAR PUSTAKA}

Abrams, M.H. 1999. A Glossary of Literary Terms. Seventh Edition. Boston: Heinle \& Heinle Publishing.

Bakhtin, M.M. 2001. "from Discourse in the Novel". Dalam Leitch, Vincent B.
(Ed). 2001. The Norton Anthology of Theory and Criticism. New York: W.W. Norton \& Company, Inc. (Hal . 1192).

Booker, M. K. 1996. A Practical Introduction to Literary Theory and Criticism. New York: Longman Publisher.

Eagleton, T. 1996. Literary Theory: An Introduction. Second Edition. Oxford: Blackwell Publisher, ltd.

Pechey, G. 2007. Mikhail Bakhtin: The Word in the World. Oxon: Routledge.

Selden, R., Widdowson, P., \& Brooker, P. 2005. A Reader's Guide to Contemporary Literary Theory. Fifth Edition. Edinburgh: Pearson Education.

Tahar Ben Jelloun. 2010. Korupsi. Jakarta: PT. Serambi Ilmu Semesta. (Diterjemahkan oleh Okke K.S. Zaimar dari judul asli L'Homme Rompu, terbitan Editions du Seuil, Paris, 1994).

Williams, J. 2004. Theory and the Novel: Narrative Reflexivity in the British Tradition. Cambridge: Cambridge University Press. 